with the latter's "Broad Church" concept arrives at a center point midst Unitarians, Evangelicals, and Tractarians. Part of a three-volume work, this third volume attempts rather conclusively to show that worship rather than theology points the way to a true understanding of church history.

The two Georges on the other hand deal with the theological arguments between Puritan, Anglican, and Catholic and treat all phases of church and civil life, ranging from salvation, sin, faith, and predestination to the relationship of English Protestantism to state and society. Basing their conclusions on the reading of great numbers of sermons, the Georges show that the basic similarities between Anglican and Puritan far outweighed their differences, most of which were political rather than theological. Of special interest is the treatment of Archbishop Laud, which proves that he had more things in common with his enemies than most political historians will allow. The study further proves that most Protestant divines had a real moral objection to the "spirit of capitalism." Here the Georges take a firm stand against the Weber thesis relating to Calvinism and capitalism.

Davies is more concerned with the form of religion as expressed in liturgy, hymnody, and architecture. He runs the gamut on church building-from Wren's auditory churches and the Unitarian meeting houses of the late seventeenth and early eighteenth centuries to the Gothic Tractarian churches of the nineteenth century, which stressed the sacramental, the sacrificial, and the central, mysterious high altar. He shows how the liturgy and architecture of a church definitely reflect an attitude toward theology, be it the Deism of the eighteenth century or the Christian Socialism of the nineteenth. His analysis of the preaching techniques of Whitefield and Wesley is superb, as is his treatment of worship by Unitarians, Evangelicals, Radicals, and Tractarians. Of special value is his pointing out how the Quakers became conformists in their nonconformity and how the first- and second-generation Tractarians differed especially in their attitude towards ritual. He shows that the critics of the Tractarians made them more ritualistic and that the fight between the Tractarians and the Evangelicals made their Protestant foes even more Protestant.

Davies has many heroes: Wesley because he made the Methodist movement as much a sacramental as an evangelical revival; the Tractarians because of their long-term effect on theology, sacred scholarship, liturgy, and religious life; and F. D. Maurice because he refused to take the extreme Evangelical view on the one side and the extreme Tractarian view on the other. To Davies, Maurice was responsible for the magnificent liturgical legacy which gave the Anglican church a blood transfusion, which in turn made it possible for that church to encompass reason, emotion, and aesthetics within the framework of a single ecclesiastical structure. Maurice, Davies believes, also preserved Liberalism for the Anglican church.

Both books show extensive research and a real understanding of the subject matter. The Georges perhaps dipped a little more deeply into their material, but Davies has put his book together in a more interesting fashion. Both books will be consulted by future historians working on British religious history between the years 1570 and 1850.

Chairman
Department of History
Coe College
Cedar Rapids
Iowa

Benjamin Sacks. The Religious Issue in the State Schools of England and Wales, 1902-1914: A Nation's Quest for Human Dignity. Pp. ix, 292. Albuquerque: University of New Mexico Press, 1961. $\$ 5.00$.

Professor Benjamin Sacks's account of the struggle between religious and secular Education in England during the opening years of the twentieth century is an excellent monograph on one phase of the interminable problem of Church and State. Even in the United States we have had 
of late such school issues as "released time" for religious instruction, grants and loans to private schools, and the question of public aid for bus rides to denominational schools and for books used in the classroom. But the British problem was far more complex than ours because England came very late to the plan of statedirected education, and ecclesiastical authorities had already a great vested interest in "voluntary schools." As the author points out, on every phase of the question there stood, arrayed for battle, the Anglican, supporting the Established Church of England; the nonconformist, traditionally suspicious of the Establishment, but vaguely desirous of some form of "Bible teaching"; the Roman Catholic, who regarded secular teaching as "godless" and the plain Bible reading as slanted towards Protestantism; and the secularist, who favored no religious instruction at all in the tax-supported schools. In this context, it should be noted, "secularist" means more than anticlerical or agnostic, it includes some devout believers who objected to formal Bible lessons in school as deadening to true religious spontaneity.

With the English genius for compromise, Parliament had at first tried to meet objections by the Cowper-Temple clause in the education act "that no catechism or religious formulary which is distinctive of any particular denomination shall be taught." Also, children could be withdrawn from school at certain times if their parents objected to the religious teaching then given. But some people found this undenominational teaching, in the words of Father Vaughan, "boneless, fibreless, structureless, tasteless religion, absolutely wanting in every constituent needed to build up the Christian character" (p. 184). On the other hand, when it seemed that their tax money might be used to support Anglican teaching, some nonconformists, led by Dr. Clifford, refused to pay their taxes in a "passive resistance" movement against subsidizing the voluntary schools. Seizure of personal property, disenfranchisement, even imprisonment followed such tax defiance, but the movement did not become general, as it was too obvious that under all governments and all laws some tax money is spent for purposes that some minority of the taxpayers does not approve. One is reminded of Thoreau's refusal to pay taxes to a "slavery" government and of the tax refusals of certain pacifists today. Another problem was the selection of teachers for religious instruction. If they were part of the regular staff, either religious tests would have to be imposed on the profession or there would be the possibility of religious instruction being given by disbelievers.

One cannot say that these problems have ever been solved. Some, however, have been by-passed, and perhaps there is less intensity of denominational feeling under the new act of 1944 than there was at the opening of the century. "In 1902 the Church of England taught more than onehalf of the nation's pupils, in 1958 less than one-fifth" (p. 223).

\section{Professor of History}

Preston Slosson

University of Michigan

Maurice F. Neufeld. Italy, School for Awakening Countries: The Italian Labor Movement in Its Political, Social, and Economic Setting From 1800 to 1960. Pp. viii, 589. Ithaca, N. Y.: New York State School of Industrial and Labor Relations, Cornell University, 1961. $\$ 9.00$.

This brilliant work examines a great paradox: Organized labor in Italy has long had a large and turbulent membership, has leaned far to the left and, yet, has been remarkably weak and ineffectual. Professor Neufeld demonstrates that Italian labor movements have suffered from the following: (1) "class" unions, instead of "category" unions; (2) powerless shop committees; (3) revolutionary and utopian political aims at the expense of short-term bargaining and reform; (4) localized action or nationwide action, to the neglect of unified action concentrated in a single industry or trade within a homogeneous economic area; (5) misdirected riots, seizures of property, and partisan warfare without supplementary measures and, at 